\title{
Comparing factors affecting commencement and cessation of betel quid chewing behavior in Taiwanese adults Shue-Fang Yap ${ }^{1}$, Pei-Shan $\mathrm{Ho}^{1}$, Hsiao-Ching $\mathrm{Kuo}^{1}$ and Yi-Hsin Yang ${ }^{* 1,2}$
}

Address: ${ }^{1}$ Faculty of Dental Hygiene, College of Dental Medicine, Kaohsiung Medical University, Taiwan and ${ }^{2}$ Statistical Analysis Laboratory, Division of Clinical Research, Kaohsiung Medical University Chung-Ho Memorial Hospital, Kaohsiung Medical University, Taiwan

Email: Shue-Fang Yap - fionayap2000@gmail.com; Pei-Shan Ho - psho@cc.kmu.edu.tw; Hsiao-Ching Kuo - u9558002@cc.kmu.edu.tw; YiHsin Yang* - yihsya@kmu.edu.tw

* Corresponding author

Published: 5 June 2008

BMC Public Health 2008, 8:199 doi:10.1 186/147|-2458-8-199
Received: I February 2008

Accepted: 5 June 2008

This article is available from: http://www.biomedcentral.com/I47I-2458/8/199

(c) 2008 Yap et al; licensee BioMed Central Ltd.

This is an Open Access article distributed under the terms of the Creative Commons Attribution License (http://creativecommons.org/licenses/by/2.0), which permits unrestricted use, distribution, and reproduction in any medium, provided the original work is properly cited.

\begin{abstract}
Background: Betel quid is the fourth most common used substance in the world after tobacco, alcohol and caffeine. Although factors related to betel quid chewing or cessation of behaviors were reported previously, few studies simultaneously compared both behaviors in the same population. In addition, it is essential to consider time-to-event concept, since the chance of developing or stopping habit may vary over time. The purpose of this study was to compare the risk factors for commencement and cessation of betel quid chewing behaviors in a time-to-event setting.
\end{abstract}

Methods: A stratified multi-stage cluster sampling with selection probabilities proportional to size (PPS) was designed for Taiwanese adults with aged 18 years old and above. Kaplan-Meier estimates and Cox proportional hazard regression models were used to compare and calculate the hazard rate ratios for related factors to commencement or cessation of chewing habits.

Results: In Taiwan, men had a higher betel quid chewing rate (M: 20.9\%, W: $1.2 \%$ ), but woman chewers had a lower cessation rate (M: 27.5\%, W: 12.7\%). The hazard rate ratio (HRR) of having chewing habit changed from 4.22 (men vs women) univariately to 1.38 multivariablely, which indicated gender differences were confounded by other factors. In multivariable analysis, the risk factors of gender, education and ethnicity were significantly associated with both starting and cessation of betel quid chewing behavior. The factors of occupation, cigarette smoking and alcohol drinking were only associated with starting habit.

Conclusion: Commencement or cessation of chewing behavior involves a scenario of time, hence it is preferable to use a time-to-event approach for the comparison. The cessation rates of betel quid chewing were decreasingly associated with the daily consumption of betel quid. Hence, reducing of daily amount in betel quid cessation program may be associated with future stopping habit.

\section{Background}

Betel quid is the fourth most universally used substance in the world after tobacco, alcohol and caffeine [1]. It is chewed periodically by at least $10 \%$ of the worlds popula- tion (600 million persons) globally [1], and it is estimated that $10 \%$ of the population ( 2 million persons) in Taiwan chew betel quid [2]. In several south, Southeast Asian and Asia Pacific communities, betel quid is chewed for many 
reasons, including for its psychostimulating effect, as well as a social and cultural practice [3]. Scientific evidence has shown that chewing betel quid contributes independently to the risk of oral cancer, oral mucosal lesions, oral leukoplakia and oral submucous fibrosis [3]. These relevant health risks emphasize the necessity for betel quid cessation. Betel quid chewing is a serious public health issue in Taiwan, and an effective strategy is necessary to implement betel quid cessation [3].

Commencement and cessation of chewing behavior has been discussed in numerous studies. However, there has been limited research to investigate both behaviors in the same study population. The purpose of this study was to use a community survey database to compare the risk factors associated with betel quid chewing, and cessation behavior. In addition, we investigated for the most commonly seen gender differences and, whether they are confounded by other effects.

\section{Methods}

\section{Study population and survey sampling design}

A stratified multi-stage cluster sampling with selection probabilities proportional to size (PPS) was designed to conduct and collect study participants. The study participants were residents of Taiwan aged 18 years old and above. Residents from the military, hospitals, rehabilitation institutes, schools, dormitories and correctional facilities were excluded from the sampling frame. In this survey, the stratification factors included geographical area, gender and age groups. The whole of Taiwan was divided into 26 strata, which included Taipei City, Kaohsiung City, 21 cities/counties, and 3 aboriginal areas. Within each geographical stratum, there were 8 strata, 2 gender groups (male and female) versus 4 age groups (18-34 years old, 35-49 years old, 50-64 years old and 65 years old or older).

The sample size for each geographical area was 400 (the actual number was 385 rounded to the nearest hundred). This number was determined by allowing 95\% confidence intervals within $3 \%$ of the range for a prevalence of $10 \%$. For some areas where the prevalence rates were from $1 \%$ to $50 \%$, their $95 \%$ confidence interval was maintained within $\pm 1 \%$ to $\pm 5 \%$. In order to maintain a large enough sample size for statistical power within each area/sex/age strata, a sample size of 400 within each area strata was equally divided into 8 gender/age strata. The estimated mean was then weighted according to the proportion of age/gender. The household registry of 2001 was used as the sampling frame.

\section{Questionnaire interview}

Public health workers were trained to conduct personal interviews using a standard structured questionnaire. The questionnaire included demographic information, and details of betel quid chewing habit (average daily amount, type of quid, age of initial betel quid chewing, and age of cessation). A lifetime betel quid chewer was defined as a person who chewed at least one quid within a week for at least 6 months. Current betel quid chewers were those who currently have the chewing habit. Former betel quid chewers were defined as a person who had stopped the chewing habit for at least 6 months. There are three types of quid in Taiwan, betel quid is made with an unripe areca fruit and slaked lime paste with a piece of betel leaf. Laohwa quid is made with a piece of inflorescence of Piper Betle Linn, and red lime paste (slaked lime and some local flavoring) placed into an unripe areca fruit. Stem quid is made with the stem of Piper Betle Linn into an unripe areca fruit.

\section{Statistical analysis}

The estimated population proportions and mean were weighted according to the population structure. There were a total of 208 strata $(26$ areas $\times 8$ sex/age $=208)$. The population size of age 18 years old or older in 2001 was first obtained for each strata $\left(\mathrm{N}_{\mathrm{i}}, \mathrm{i}=1\right.$ to 208$)$. Let the sample size of each strata be $n_{i}(i=1$ to 208), then the weight for each strata can be obtained by $\mathrm{W}_{\mathrm{i}}=\frac{N_{i}}{n_{i}} \bullet \frac{n}{N}$, where $\mathrm{N}=\sum_{i=1}^{208} N_{i}, \mathrm{n}=\sum_{i=1}^{208} n_{i}$ and the "i" is one of the area/sex/ age strata. SUDAAN software was used to implement the statistical computation for proportions and $95 \%$ confidence intervals were used to show the precision of estimates. In addition, the relation between sociodemographic characteristics and lifestyle habits were computed by chi-square test.

To investigate the commencement and cessation of betel quid chewing behavior in terms of time (age in years), the Kaplan-Meier estimate was used to calculate the hazards rate for life time betel quid chewers and former chewers. There were two events in this study. The first event is a person who started betel quid chewing behavior. The followup period for the time-to-event was length of time between birth to the age of starting betel quid chewing behavior. The second event is the person who had stopped chewing behavior. The follow-up for the time-toevent were length of time between ages of start chewing behavior to the age of stop betel quid chewing. The logrank test was used to compare the difference among the groups. Furthermore, the Cox proportional hazard regression model was used to calculate the hazard rate for factors related to commencement or cessation of chewing habits. P-values lower than 0.05 were considered statisti- 
Table I: Prevalence of betel quid chewing behavior between men and women for different demographics characteristics

\begin{tabular}{|c|c|c|c|c|c|c|c|c|c|}
\hline \multirow[t]{3}{*}{ Variables } & \multirow[t]{3}{*}{ Item } & \multicolumn{8}{|c|}{ Betel quid chewers } \\
\hline & & \multicolumn{4}{|c|}{ Male } & \multicolumn{4}{|c|}{ Female } \\
\hline & & $\begin{array}{r}\text { Adjusted } \\
\text { sample size }\end{array}$ & $\%$ & $\begin{array}{l}\text { 95\% Confidence } \\
\text { Interval }\end{array}$ & P-value & $\begin{array}{r}\text { Adjusted } \\
\text { sample size }\end{array}$ & $\%$ & $\begin{array}{l}\text { 95\% Confidence } \\
\text { Interval }\end{array}$ & P-value \\
\hline Total & & 5922 & 20.9 & $(19.2,22.6)$ & & 5747 & 1.2 & $(1.0,1.6)$ & \\
\hline \multirow[t]{4}{*}{ Age group } & $18-34$ & 2682 & 21.0 & $(18.1,24.2)$ & $<.0001$ & 2597 & 0.6 & $(0.4,1.1)$ & 0.0017 \\
\hline & $35-49$ & 1790 & 23.9 & $(21.0,27.0)$ & & 1769 & 1.6 & $(1.0,2.6)$ & \\
\hline & $50-64$ & 919 & 20.8 & $(18.5,23.3)$ & & 925 & 1.7 & $(1.2,2.3)$ & \\
\hline & 65 and above & 531 & 10.4 & $(8.9,12.2)$ & & 456 & 2.3 & $(1.7,3.1)$ & \\
\hline \multirow[t]{5}{*}{ Education \# } & Literate & 283 & 19.0 & $(15.3,23.3)$ & $<.0001$ & 653 & 2.2 & $(1.7,2.9)$ & $<.0001$ \\
\hline & Primary school & 921 & 26.4 & $(23.3,29.7)$ & & 1153 & 2.8 & $(2.1,3.6)$ & \\
\hline & Junior high school & 1021 & 32.1 & $(27.6,36.9)$ & & 802 & I.I & $(0.6,1.9)$ & \\
\hline & Senior high school & 2100 & 25.6 & $(22.3,29.3)$ & & 1775 & 0.9 & $(0.4,2.1)$ & \\
\hline & College and above & $|57|$ & 4.6 & $(3.2,6.5)$ & & 1345 & 0.0 & $(0.0,0.1)$ & \\
\hline \multirow[t]{4}{*}{ Occupation \# } & $\begin{array}{l}\text { Unemployed or } \\
\text { non-technical }\end{array}$ & 2903 & 19.5 & $(17.3,21.9)$ & $<.0001$ & 3893 & 1.4 & $(1.1,1.8)$ & 0.0731 \\
\hline & Technical & 1488 & 29.8 & $(26.4,33.4)$ & & 649 & 1.5 & $(1.0,2.2)$ & \\
\hline & Semi-professional & 865 & 18.2 & $(13.8,23.7)$ & & 895 & 0.7 & $(0.1,3.6)$ & \\
\hline & $\begin{array}{l}\text { Managerial/ } \\
\text { professional and } \\
\text { above }\end{array}$ & 561 & 7.4 & $(4.1,13.1)$ & & 310 & 0.0 & $(0.0,0.1)$ & \\
\hline \multirow[t]{2}{*}{ Ethnicity \# } & Aborigines & 111 & 54.3 & $(44.9,63.5)$ & $<.0001$ & 106 & $\begin{array}{r}33 . \\
8\end{array}$ & $(28.1,39.9)$ & $<.0001$ \\
\hline & Non-aborigines & 5797 & 20.2 & $(18.6,22.0)$ & & 5631 & 0.6 & $(0.4,1.0)$ & \\
\hline \multirow[t]{2}{*}{$\begin{array}{l}\text { Cigarette } \\
\text { smoker \# }\end{array}$} & Yes & 2979 & 37.1 & $(34.2,40.1)$ & $<.0001$ & 190 & $\begin{array}{r}14 . \\
8\end{array}$ & $(8.6,24.1)$ & $<.0001$ \\
\hline & No & 2918 & 4.4 & $(3.5,5.5)$ & & 5553 & 0.8 & $(0.6,0.9)$ & \\
\hline \multirow[t]{2}{*}{$\begin{array}{l}\text { Alcohol } \\
\text { drinker }\end{array}$} & Yes & 815 & 51.7 & $(46.3,57.2)$ & $<.0001$ & 60 & $\begin{array}{r}21 . \\
0\end{array}$ & $(14.5,29.4)$ & $<.0001$ \\
\hline & No & 5107 & 16.0 & $(14.4,17.7)$ & & 5687 & 1.0 & $(0.8,1.4)$ & \\
\hline
\end{tabular}

\#: 26 males and 19 females with missing value in education; 105 males with missing value in occupation; 14 males and 10 females with missing value in ethnicity; 25 males and 4 females with missing value in cigarette smoker

cally significant. These analyses were conducted by the Statistical Analysis System (SAS Inc.).

\section{Results}

There were 11,723 participants in this survey which 54 participants without complete information on chewing habit were excluded from the analysis. The prevalence rates of betel quid chewing between men and women in different demographic characteristics are shown in Table 1 . The results showed that males $(20.9 \%)$ had a higher betel quid chewing rate than females $(1.2 \%)$. In each variable, males had a higher betel quid chewing rate than females. In terms of age, males aged 35-49 years old $(23.9 \%)$ had the highest chewing rate, while females aged 65 years old and above $(2.3 \%)$ had the highest rate. In regards to education level, males with junior high school level and females with primary school level were the highest categories among the betel quid chewers $(32.1 \%$ and $2.8 \%$, respectively). For both genders, persons with college education and above had the lowest proportion of chewers. The highest betel quid chewing for occupation were technical (males $29.8 \%$ and females $1.5 \%$ ). In an aboriginal population the highest chewing prevalence were in both genders. Moreover, more cigarette smokers and alcohol drinkers also had chewing behavior.

For people with a lifetime chewing habit, the proportion of those who stopped the chewing habit for at least 6 months is shown in Table 2. Females had a lower cessation rate than males ( $12.7 \%$ and $27.5 \%$, respectively). The 


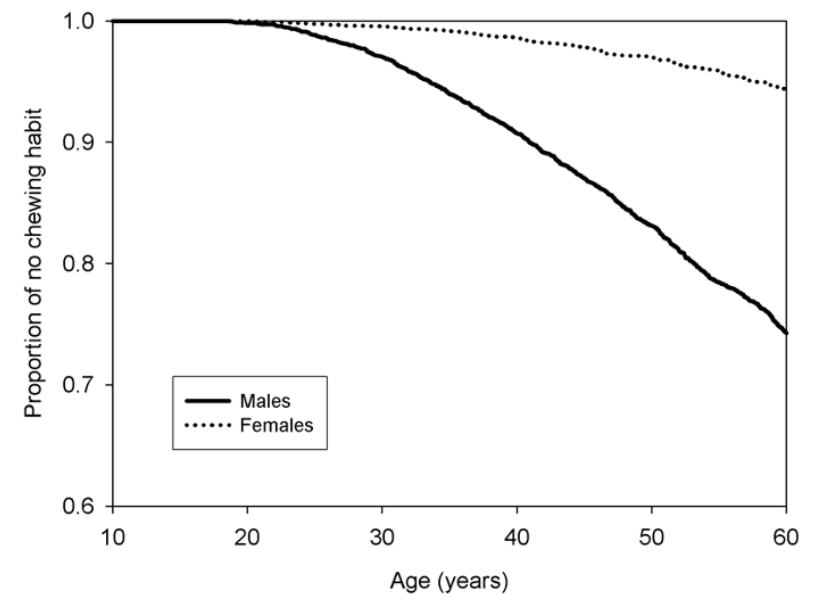

Figure I

From birth to commencement of betel quid chewing between males and females.

proportion of those who quit the chewing habit was statistically significantly different in age group ( $\mathrm{p}<.0001)$, education ( $\mathrm{p}=0.0003)$, ethnicity $(\mathrm{p}=0.0004)$, cigarette smoking $(\mathrm{p}=0.0113)$ and type of quid $(\mathrm{p}<.0001)$ in males. However, none of the factors were statistically significantly different in females. In terms of age groups, more elderly people (age 65 years old and above) quit the chewing habit (males 50.5\%, females 22.1\%). In all categories fewer females quit the chewing habit than males.

To estimate the time (age in years) to commencement of the chewing habit, and the time (age in years) to cessation of the chewing habit between males and females, the Kaplan-Meier estimates are computed and plotted in Figure 1 and 2. The curve for the age of women starting the habit was above the curve of men, which indicated that women were less likely to develop the chewing habit. The chewers began chewing betel quid at 16 years old. Figure 2 shows that the curve for the age of women stopping the chewing habit was above the curve of men, this showed that women are less likely to stop betel quid chewing. Both lines were approximately linear, which indicates that there were no peak time intervals for developing or stopping the chewing habit. Therefore, cessation of the chewing habit happens all the time in both genders. Log-rank tests indicated that the p-values were significant $(\mathrm{p}<$ 0.0001 ) for both betel quid chewing and betel quid cessation.

To evaluate the factors related to stopping the betel quid chewing habit between men and women in terms of time, the hazard rate had estimates by univariate and multivariable Cox-regression as shown in Table 3. When considering developing chewing habits, in univariate analysis

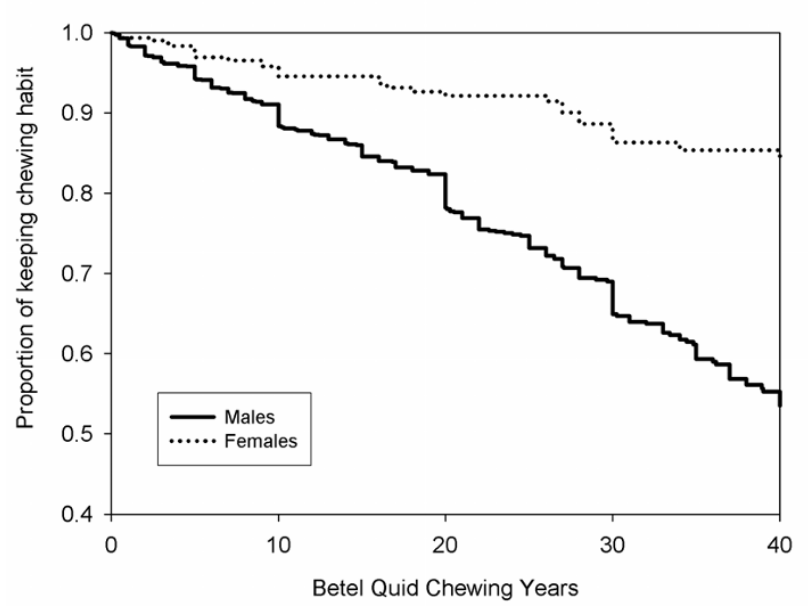

Figure 2

Commencement to cessation of betel quid chewing between males and females. Refer to main text for details.

most factors were statistically significant, and for men $(\mathrm{HR}=4.22,95 \% \mathrm{CI}=3.74-4.77, \mathrm{p}<.0001)$, education of junior high school $(\mathrm{HR}=2.25,95 \% \mathrm{CI}=2.00-2.54, \mathrm{p}<$ $.0001)$, senior high school $(\mathrm{HR}=2.58,95 \% \mathrm{CI}=2.31-$ 2.89 , $\mathrm{p}<.0001)$, technical $(\mathrm{HR}=3.12,95 \% \mathrm{CI}=2.81-$ $3.47, \mathrm{p}<.0001)$, Taiwan aborigines $(\mathrm{HR}=4.41,95 \% \mathrm{CI}=$ $4.00,4.87, \mathrm{p}<.0001)$, smokers $(\mathrm{HR}=7.04,95 \% \mathrm{CI}=$ $6.32-7.85, \mathrm{p}<.0001)$ and drinkers $(\mathrm{HR}=4.46,95 \% \mathrm{CI}=$ 4.04-4.92, $\mathrm{p}<.0001$ ) all had higher risk (hazard rate). However, in multivariable Cox-regression the risk of men starting chewing behavior became lower $(\mathrm{HR}=1.38$, $95 \% \mathrm{CI}=1.20-1.59, \mathrm{p}<.0001)$. Hence, the phenomenon of more males developing the habit may be affected by others factors in the model.

When considering years to stop chewing behavior, men were more likely to stop chewing than women in multivariable analysis was shown in Table $4(\mathrm{HR}=1.73,95 \% \mathrm{CI}$ $=1.14-2.64, \mathrm{p}=0.0107)$. The most likely subgroup of stopping chewing behavior were men, college and above education, semi-professional occupation, non-aborigines, non-smokers, non-drinkers, type of quid and daily betel quid chewing number. Furthermore, daily betel quid chewing consumption of 30 pieces or more $(\mathrm{HR}=0.69$, $95 \% \mathrm{CI}=0.52-0.90, \mathrm{p}=0.0070)$, and 100 pieces or more $(\mathrm{HR}=0.57,95 \% \mathrm{CI}=0.30-1.07, \mathrm{p}=0.0785)$ were significantly less likely to stop chewing in multivariable analysis. Lao-hwa quid was the highest cessation of chewing type of quid in our study, they were 1.71 times more likely to stop chewing. In addition, those who chew a mixture of betel quid and Lao-hwa quid were 1.70 times more likely to stop chewing behavior. 
Table 2: Proportion of chewers stopping chewing habit between men and women in different demographic characteristics

\begin{tabular}{|c|c|c|c|c|c|c|c|c|c|}
\hline \multirow[t]{3}{*}{ Variable } & \multirow[t]{3}{*}{ Item } & \multicolumn{8}{|c|}{$\%$ of stop chewing habit } \\
\hline & & \multicolumn{4}{|c|}{ Male } & \multicolumn{4}{|c|}{ Female } \\
\hline & & $\begin{array}{r}\text { Adjusted } \\
\text { sample size }\end{array}$ & $\%$ & $\begin{array}{l}\text { 95\% Confidence } \\
\text { Interval }\end{array}$ & P-value & $\begin{array}{r}\text { Adjusted } \\
\text { sample size }\end{array}$ & $\%$ & $\begin{array}{l}95 \% \text { Confidence } \\
\text { Interval }\end{array}$ & P-value \\
\hline Total & & 1237 & 27.5 & $(23.8,31.6)$ & & 71 & 12.7 & $(7.5,20.8)$ & \\
\hline \multirow[t]{4}{*}{ Age group } & $18-34$ & 563 & 21.9 & $(15.7,29.7)$ & $<.0001$ & 17 & 4.3 & $(1.4,12.2)$ & 0.5351 \\
\hline & $35-49$ & 428 & 26.4 & $(21.1,32.5)$ & & 29 & 11.7 & $(3.9,30.5)$ & \\
\hline & $50-64$ & 191 & 40.0 & $(33.8,46.6)$ & & 16 & 17.3 & $(7.4,35.5)$ & \\
\hline & 65 and above & 55 & 50.5 & $(41.9,59.1)$ & & 9 & 22.1 & (I I.2, 38.8) & \\
\hline \multirow[t]{5}{*}{ Education \# } & Literate & 54 & 42.5 & $(31.4,54.3)$ & 0.0003 & 14 & 16.7 & $(7.8,32.3)$ & 0.6409 \\
\hline & Primary school & 243 & 35.1 & $(28.9,41.7)$ & & 32 & 17.1 & $(8.3,32.0)$ & \\
\hline & Junior high school & 328 & 22.6 & $(16.5,30.1)$ & & 9 & 10.3 & $(3.1,28.8)$ & \\
\hline & Senior high school & 538 & 24.8 & $(18.5,32.3)$ & & 16 & 1.9 & $(0.4,8.7)$ & \\
\hline & College and above & 72 & 35.2 & $(19.2,55.4)$ & & 0 & 0.0 & $(-,-)$ & \\
\hline \multirow[t]{4}{*}{ Occupation } & $\begin{array}{l}\text { Unemployed or non- } \\
\text { technical }\end{array}$ & 564 & 30.8 & $(25.2,37.0)$ & 0.1301 & 55 & 16.4 & $(9.8,26.1)$ & 0.4067 \\
\hline & Technical & 473 & 24.5 & $(19.3,30.7)$ & & 10 & 0.7 & $(0.1,4.9)$ & \\
\hline & Semi-professional & 158 & 25.0 & $(14.2,40.2)$ & & 6 & 0.0 & $(-,-)$ & \\
\hline & $\begin{array}{l}\text { Managerial/ } \\
\text { professional and } \\
\text { above }\end{array}$ & 42 & 27.2 & $(9.6,56.9)$ & & 0 & 0.0 & $(-,-)$ & \\
\hline \multirow[t]{2}{*}{ Ethnicity \# } & Aborigines & 60 & 7.8 & $(5.1,11.9)$ & 0.0004 & 36 & 9.8 & $(4.6,19.7)$ & 0.4538 \\
\hline & Non-aborigines & 1173 & 28.6 & $(24.7,32.9)$ & & 35 & 15.7 & $(7.3,30.6)$ & \\
\hline \multirow{2}{*}{$\begin{array}{l}\text { Cigarette } \\
\text { smoker \# }\end{array}$} & Yes & 1105 & 26.5 & $(22.6,30.8)$ & 0.0113 & 28 & 7.2 & $(3.2,15.7)$ & 0.2572 \\
\hline & No & 128 & 37.1 & $(26.1,49.6)$ & & 43 & 16.4 & $(9.0,28.0)$ & \\
\hline \multirow{2}{*}{$\begin{array}{l}\text { Alcohol } \\
\text { drinker }\end{array}$} & Yes & 422 & 27.9 & $(21.1,35.9)$ & 0.8412 & 13 & 5.9 & $(2.5,13.2)$ & 0.4259 \\
\hline & No & 815 & 27.4 & $(23.1,32.1)$ & & 58 & 14.2 & $(8.0,24.0)$ & \\
\hline \multirow[t]{4}{*}{ Type of quid \# } & Betel quid & 786 & 20.3 & $(16.2,25.0)$ & $<.0001$ & 55 & 13.1 & $(7.2,22.7)$ & 0.8280 \\
\hline & Lao-hwa quid & 259 & 44.1 & $(35.5,53.1)$ & & 2 & 0.0 & $(-,-)$ & \\
\hline & $\begin{array}{l}\text { Betel quid + Lao- } \\
\text { hwa quid }\end{array}$ & 134 & 31.0 & $(19.0,46.3)$ & & 6 & 6.4 & $(0.8,37.3)$ & \\
\hline & Others & 50 & 47.9 & $(27.1,69.4)$ & & 8 & 19.3 & $(6.6,44.7)$ & \\
\hline
\end{tabular}

\#: 2 males with missing value in education; 4 males with missing value in ethnicity; 4 males with missing value in cigarette smoker; 8 males with missing value in type of quid

\section{Discussion}

Many studies have discussed the factors relating to commencement of betel quid chewing as well as cessation of chewing behavior. Few studies parallelly investigated both behaviors at the same time. In this study, we used a community survey to identify possible reasons for both starting and stopping behavior.

Social expectations are different between genders in many societies, it may result in different chewing behavior among men and women. The lifetime chewing prevalence was found to be relatively low in women $(1.2 \%)$ as com- pared to men $(20.9 \%)$ in our study. Similarly, in India (men 34.5\%, women 27.2\%) [4], the Solomon Islands (men $83 \%$, women 68\%) [5] as well as current chewing prevalence in Taiwan (men 14.4\%, women 1.5\%) [6] also had a higher prevalence in men. Nevertheless, there are also societies where more women chew betel quid than men; such as Cambodia (men 3.2\%, women $8.2 \%$ ) [7], Pakistan (men 6.8\%, women 40.6\%) [8], indigenous people of Sarawak, Malaysia (men 30\%, women 63\%) [9] and Taiwan aborigines (men 60.6\%, women 78.7\%) [10]. Even so, in Thailand (men 16\%, women 19\%) [11] and Xiangtang City, China (men 39.3\%, women 30.5\%) [12] 
Table 3: Univariate and multivariable analysis of betel quid from birth until commencement of chewing betel quid

\begin{tabular}{|c|c|c|c|c|c|c|c|}
\hline \multirow[t]{2}{*}{ Variables } & \multirow[t]{2}{*}{ Item } & \multicolumn{3}{|c|}{ Univariate } & \multicolumn{3}{|c|}{ Multivariable } \\
\hline & & Hazard Rate Ratio & $\begin{array}{l}\text { 95\% Confidence } \\
\text { Interval }\end{array}$ & P-value & Hazard Rate Ratio & $\begin{array}{l}\text { 95\% Confidence } \\
\text { Interval }\end{array}$ & P-value \\
\hline \multirow[t]{2}{*}{ Sex } & Male & 4.22 & $(3.74,4.77)$ & $<.0001$ & 1.38 & $(1.20,1.59)$ & $<.0001$ \\
\hline & Female & 1.00 & & & 1.00 & & \\
\hline \multirow[t]{5}{*}{ Education } & Literate & 0.30 & $(0.26,0.34)$ & $<.0001$ & 0.47 & $(0.37,0.61)$ & $<.0001$ \\
\hline & Primary school & 1.01 & $(0.92,1.12)$ & 0.8400 & 0.92 & $(0.73,1.17)$ & 0.4969 \\
\hline & Junior high school & 2.25 & $(2.00,2.54)$ & $<.0001$ & 2.33 & $(1.83,2.97)$ & $<.0001$ \\
\hline & Senior high school & 2.58 & $(2.31,2.89)$ & $<.0001$ & 2.51 & $(1.99,3.17)$ & $<.0001$ \\
\hline & College and above & 1.00 & & & 1.00 & & \\
\hline \multirow[t]{4}{*}{ Occupation } & $\begin{array}{l}\text { Unemployed or } \\
\text { non-technical }\end{array}$ & 0.35 & $(0.3 \mathrm{I}, 0.38)$ & $<.0001$ & 0.97 & $(0.69,1.37)$ & 0.8800 \\
\hline & Technical & 3.12 & $(2.8 \mathrm{I}, 3.47)$ & $<.0001$ & 2.09 & $(1.48,2.96)$ & $<.0001$ \\
\hline & Semi-professional & 1.73 & $(1.44,2.09)$ & $<.0001$ & 1.52 & $(1.04,2.20)$ & 0.0288 \\
\hline & $\begin{array}{l}\text { Managerial/ } \\
\text { professional and } \\
\text { above }\end{array}$ & 1.00 & & & 1.00 & & \\
\hline \multirow[t]{2}{*}{ Ethnicity } & Aborigines & 4.41 & $(4.00,4.87)$ & $<.0001$ & 4.38 & $(3.94,4.87)$ & $<.0001$ \\
\hline & Non-aborigines & 1.00 & & & 1.00 & & \\
\hline \multirow[t]{2}{*}{ Cigarette smoker } & Yes & 7.04 & $(6.32,7.85)$ & $<.0001$ & 4.10 & $(3.62,4.63)$ & $<.0001$ \\
\hline & No & 1.00 & & & 1.00 & & \\
\hline \multirow[t]{2}{*}{ Alcohol drinker } & Yes & 4.46 & $(4.04,4.92)$ & $<.0001$ & 1.73 & $(1.56,1.92)$ & $<.0001$ \\
\hline & No & 1.00 & & & 1.00 & & \\
\hline
\end{tabular}

have more equal betel quid chewing prevalence between genders. The differences among men and women may be due to various reasons. When men chewed more than women, most of the time women tried to avoid redstained lips, and foul smelling breath associated with betel chewing [4]. In contrast, men chewers may develop the chewing behavior to project an image of machismo, and strength [13]. The reasons for women having a higher chewing prevalence than men are mostly for traditional cultural factors $[10,13]$.

The fact that men are less or more likely to chew betel quid has been reported in many studies. Whether gender differences fundamentally exist or are confounded by other factors as mentioned above is of interest. In our study, males were 4.22 times more likely to have chewing behavior in the univariate analysis, but were only 1.38 times more likely to have chewing behavior, after adjusting for education, occupation, ethnicity, smoking and drinking habits. It may imply that the tendency of men being more likely to chew is affected by other factors. In other words, men are more likely to chew betel quid than women due to different combinations of factors such as education, occupation, ethnicity, cigarette smoking and alcohol drinking between genders.
Those in a technical occupation were more likely to chew betel quid $(\mathrm{HR}=2.09)$ similar to a previous study in Taiwan [14]. Winstock reported that areca nut contains arecoline, a para-sympathomimetric agent, and can stimulate salivation and sweating [15]. Therefore, blue collar workers are more likely to use betel quid for its physical effects, a sense of well-being, heightened alertness, reduction of tension, and hence increasing capacity to work $[16,17]$. In addition, they might also be influenced by the social environment, and long working hours, with betel quid being perceived as a stimulant $[15,18]$. An economic reason may also play a part in the habit differences. In Taiwan, betel/areca quid are mostly sold at betel stands except for aboriginal communities. Twenty pieces of betel quid generally costs NT $\$ 100$ (US\$3.20), while a pack of cigarette (20 cigarettes) only costs NT $\$ 35$ (US\$1.10) on average. Therefore, the unemployed or those on a lower income may not be able to afford the betel quid chewing habit.

Betel quid plays an important role in Taiwan aborigines cultural activities who have a long history of chewing habits [10]. This is similar to many Southeast Asian countries and India, which also have a long history of chewing betel quid, and a cultural and social acceptance of the practice 
Table 4: Univariate and multivariable analysis of betel quid chewer to quit betel quid

\begin{tabular}{|c|c|c|c|c|c|c|c|}
\hline \multirow[t]{2}{*}{ Variable } & \multirow[t]{2}{*}{ Item } & \multicolumn{3}{|c|}{ Univariate } & \multicolumn{3}{|c|}{ Multivariable } \\
\hline & & Hazard Rate Ratio & $\begin{array}{l}\text { 95\% Confidence } \\
\text { Interval }\end{array}$ & P-value & Hazard Rate Ratio & $\begin{array}{l}\text { 95\% Confidence } \\
\text { Interval }\end{array}$ & P-value \\
\hline \multirow[t]{2}{*}{ Sex } & Male & 3.48 & $(2.44,4.97)$ & $<.0001$ & 1.73 & $(1.14,2.64)$ & 0.0107 \\
\hline & Female & 1.00 & & & 1.00 & & \\
\hline \multirow[t]{5}{*}{ Education } & Literate & 0.54 & $(0.4 I, 0.70)$ & $<.0001$ & 0.46 & $(0.28,0.76)$ & 0.0026 \\
\hline & Primary school & 0.95 & $(0.77,1.16)$ & 0.5986 & 0.59 & $(0.37,0.95)$ & 0.0294 \\
\hline & Junior high school & 1.23 & $(0.94,1.62)$ & 0.1281 & 0.67 & $(0.40,1.11)$ & 0.1156 \\
\hline & Senior high school & 1.62 & $(1.26,2.09)$ & 0.0002 & 0.74 & $(0.46,1.21)$ & 0.2309 \\
\hline & College and above & 1.00 & & & 1.00 & & \\
\hline \multirow[t]{4}{*}{ Occupation } & $\begin{array}{l}\text { Unemployed or } \\
\text { non-technical }\end{array}$ & 0.76 & $(0.62,0.93)$ & 0.0083 & 1.19 & $(0.59,2.4 I)$ & 0.6295 \\
\hline & Technical & 1.14 & $(0.92,1.43)$ & 0.2301 & 1.17 & $(0.58,2.39)$ & 0.6584 \\
\hline & Semi-professional & 1.71 & $(1.17,2.50)$ & 0.0058 & 1.46 & $(0.68,3.12)$ & 0.3315 \\
\hline & $\begin{array}{l}\text { Managerial/ } \\
\text { professional and } \\
\text { above }\end{array}$ & 1.00 & & & 1.00 & & \\
\hline \multirow[t]{2}{*}{ Ethnicity } & Aborigines & 0.29 & $(0.22,0.37)$ & $<.0001$ & 0.40 & $(0.30,0.55)$ & $<.0001$ \\
\hline & Non-aborigines & 1.00 & & & 1.00 & & \\
\hline \multirow[t]{2}{*}{ Cigarette smoker } & Yes & 1.64 & $(1.28,2.09)$ & $<.0001$ & 0.95 & $(0.73,1.25)$ & $0.726 \mathrm{I}$ \\
\hline & No & 1.00 & & & 1.00 & & \\
\hline \multirow[t]{2}{*}{ Alcohol drinker } & Yes & 0.78 & $(0.63,0.96)$ & 0.0204 & 0.81 & $(0.65,1.02)$ & 0.0679 \\
\hline & No & 1.00 & & & 1.00 & & \\
\hline \multirow[t]{4}{*}{ Type of quid } & Betel quid & 0.48 & $(0.39,0.58)$ & $<.0001$ & 0.73 & $(0.50,1.08)$ & 0.1127 \\
\hline & Lao-hwa quid & 2.63 & $(2.13,3.25)$ & $<.0001$ & 1.71 & $(1.13,2.58)$ & 0.0104 \\
\hline & $\begin{array}{l}\text { Betel quid + Lao- } \\
\text { hwa quid }\end{array}$ & 2.08 & $(1.48,2.94)$ & $<.0001$ & 1.70 & $(1.04,2.79)$ & 0.0362 \\
\hline & Others & 1.00 & & & 1.00 & & \\
\hline \multirow{5}{*}{$\begin{array}{l}\text { Daily betel quid } \\
\text { chewing amount } \\
\text { (pieces) }\end{array}$} & I-9 pieces & 1.00 & & & 1.00 & & \\
\hline & $10-19$ pieces & 0.99 & $(0.78,1.26)$ & 0.9385 & 0.81 & $(0.62,1.06)$ & 0.1276 \\
\hline & 20-29 pieces & 0.98 & $(0.77,1.26)$ & 0.8960 & 0.75 & $(0.56,0.99)$ & 0.0401 \\
\hline & 30-99 pieces & 0.87 & $(0.68,1.10)$ & 0.2489 & 0.69 & $(0.52,0.90)$ & 0.0070 \\
\hline & above 100 pieces & 0.66 & $(0.36,1.20)$ & 0.1742 & 0.57 & $(0.30,1.07)$ & 0.0785 \\
\hline
\end{tabular}

[11]. That is the reason for a high chewing prevalence among Taiwanese aborigines.

Betel quid chewing behavior in different countries may be affected by different cultural and socio-demographic factors. Cambodia has the highest chewing habit among the older population [19]. In the Solomon Islands, education level and cigarette smoking habit are associated with betel quid chewing behavior [5]. Previous studies in Taiwan have shown that gender, education level, occupation, ethnicity, cigarette smoking and alcohol drinking are associated with betel quid chewing $[6,20]$.
Betel quid prevention has become an important health issue recently. It is related to oral disease and other health problems, such as asthma [21], cardiovascular disease [22], diabetes mellitus [23,24], periodontal disease [25], oral submucous fibrosis [16,26], and oral cancer [25]. Hence these act as an important factor in betel quid prevention and cessation strategies to reduce oral disease.

Our findings indicate that though betel quid chewing is more common among male chewers, but female chewers are less likely to stop chewing betel quid (male 27.5\%, female $12.7 \%$ ). Previous studies in Taiwan also showed that prevalence of betel quid cessation (males $12.8 \%$, females $0.9 \%$ [27], males $45 \%$, females $0.2 \%$ [6], and Tai- 
wan aboriginal males $8.2 \%$, females $6.7 \%$ [20]) were lower among the women chewers. In our study, men are 1.73-fold more likely than women to stop chewing.

In general, previous studies showed that education level, occupation, alcohol drinking, and cigarette smoking are related to cessation of betel quid chewing $[6,18,20]$. In addition, our study showed that gender, ethnicity and type of quid are significant factors associated with betel quid cessation behavior among chewers in terms of time. Women had a lower betel quid chewing rate and cessation of chewing rate than men in terms of time. Moreover, the time-to-event curves were linearly decreased over time, which indicated that cessation of the chewing habit happens all the time in both genders. The older population had the highest betel quid chewing cessation prevalence, which may be due to health problems. A recent study also showed that Taiwan aborigines $(\mathrm{aOR}=0.40,95 \% \mathrm{CI}=$ 0.24-0.68) were less likely to stop chewing than non-Taiwan aborigines [20], similar to our study. It may be related to culture and tradition among the aborigines [10], thus the betel quid cessation is lower in this population.

In our findings, chewers with high daily consumption were less likely to stop chewing behavior. A recent study pointed out that the fewer pieces of betel quid chewed the more likely they were to stop chewing behavior which was similar to our finding (but not significantly) [20]. Betel quid was the most popular type of quid in this study. Nevertheless people who chew Lao-hwa quid had the highest rate of cessation $(\mathrm{HR}=1.71)$. Moreover, those who chew mixtures of betel quid and Lao-hwa quid are 1.70 times more likely to stop chewing behavior. Lao-hwa quid is commonly seen in urban areas, it is made with a piece of inflorescence of Piper Betle Linn, and red lime paste (slaked lime and some local flavoring) into an unripe areca fruit [10]. Betel quid generally contains more slaked lime than Lao-hwa quid. Hence, the flavor is stronger than Lao-hwa quid. Therefore, it is less likely for betel quid chewers to stop chewing behavior.

\section{Conclusion}

Commencement or cessation of chewing betel quid behavior involves a scenario of time-to-event, hence it is preferable to consider the analysis in terms of time (years to events). In this study, we found that women had a lower chewing behavior rate, but they were less likely to stop chewing than men. The factors related to the betel quid chewing habit and cessation is not parallel. This phenomenon has an impact on the social background of the chewers, such as occupation, education, ethnicity, cigarette smoking and alcohol drinking. As regard to whether betel quid chewing cessation has an impact on gender, ethnicity and type of quid, male chewer's serve as the major focus in betel quid chewing prevention programs. The cessation rates of betel quid chewing were decreasingly associated with the daily consumption of betel quid. Hence, reducing of daily amount in betel quid cessation program may be associated with future stopping habit.

\section{Competing interests}

The authors declare that they have no competing interests.

\section{Authors' contributions}

S-FY carried out the studies, participated in the sequence alignment, performed the statistical analysis and drafted the manuscript. P-SH participated in the design of the study. H-CK performed the statistical analysis. Y-HY led this study, and participated in its design and coordination and helped to draft the manuscript. All authors read and approved the manuscript.

\section{Acknowledgements}

The research is supported in part by grant (DOH92-TD-I I35) from the Bureau of Health Promotion, Department of Health, Taiwan, R.O.C.

\section{References}

I. Gupta PC, Warnakulasuriya S: Global epidemiology of areca nut usage. Addict Biol 2002, 7(I):77-83.

2. Yang YH, Chen HR, Tseng CH, Shieh TY: Prevalence rates of areca/betel quid chewing in counties of Taiwan (in Chinese). Taiwan J Oral Med Health Sci 2002, 18: I-16.

3. Betel-quid and areca-nut chewing and some areca-nut derived nitrosamines. IARC Monogr Eval Carcinog Risks Hum 2004, 85: I-334.

4. Gupta PC: Survey of sociodemographic characteristics of tobacco use among $\mathbf{9 9 , 5 9 8}$ individuals in Bombay, India using handheld computers. Tob Control 1996, 5(2): | | 4- I20.

5. Tovosia S, Chen PH, Ko AM, Tu HP, Tsai PC, Ko YC: Prevalence and Associated Factors of Betel Quid Use in the Solomon Islands: A Hyperendemic Area for Oral and Pharyngeal Cancer. Am J Trop Med Hyg 2007, 77(3):586-590.

6. Wen CP, Tsai SP, Cheng TY, Chen CJ, Levy DT, Yang HJ, Eriksen MP: Uncovering the relation between betel quid chewing and cigarette smoking in Taiwan. Tob Control 2005, I 4(SuppI I): i 6-22.

7. Ikeda N, Handa Y, Khim SP, Durward C, Axell T, Mizuno T, Fukano $\mathrm{H}$, Kawai T: Prevalence study of oral mucosal lesions in a selected Cambodian population. Community Dent Oral Epidemiol 1995, 23(I):49-54.

8. Jafarey NA, Zaidi SH: Carcinoma of the oral cavity and oropharynx in Karachi (Pakistan). An appraisal. Trop Doct 1976, 6(2):63-67.

9. Strickland SS, Duffield AE: Anthropometric status and resting metabolic rate in users of the areca nut and smokers of tobacco in rural Sarawak. Ann Hum Biol 1997, 24(5):453-474.

10. Yang YH, Lee HY, Tung S, Shieh TY: Epidemiological survey of oral submucous fibrosis and leukoplakia in aborigines of Taiwan. J Oral Pathol Med 200I, 30(4):213-219.

II. Reichart PA, Mohr U, Srisuwan S, Geerlings H, Theetranont C, Kangwanpong T: Precancerous and other oral mucosal lesions related to chewing, smoking and drinking habits in Thailand. Community Dent Oral Epidemiol 1987, I 5(3): 152-160.

12. Tang JG, Jian XF, Gao ML, Ling TY, Zhang KH: Epidemiological survey of oral submucous fibrosis in Xiangtan City, Hunan Province, China. Community Dent Oral Epidemiol 1997, 25(2): 177-180.

13. Williams S, Malik A, Chowdhury S, Chauhan S: Sociocultural aspects of areca nut use. Addict Biol 2002, 7(I): 147-I54.

14. Ko YC, Chiang TA, Chang SJ, Hsieh SF: Prevalence of betel quid chewing habit in Taiwan and related sociodemographic factors. J Oral Pathol Med 1992, 21(6):26I-264.

15. Winstock $A$ : Areca nut-abuse liability, dependence and public health. Addict Biol 2002, 7(I): 133-138. 
16. Shiu MN, Chen TH, Chang SH, Hahn LJ: Risk factors for leukoplakia and malignant transformation to oral carcinoma: a leukoplakia cohort in Taiwan. Br J Cancer 2000, 82(I I): I87I-I874.

17. Chu NS: Sympathetic response to betel chewing. J Psychoactive Drugs 1995, 27(2): 183-186.

18. Lai CS, Shieh TY, Yang YH, Chong MY, Hung HC, Tsai CC: Factors associated with quitting areca (betel) quid chewing. Community Dent Oral Epidemiol 2006, 34(6):467-474.

19. Reichart PA, Schmidtberg W, Scheifele C: Betel chewer's mucosa in elderly Cambodian women. J Oral Pathol Med 1996, 25(7):367-370.

20. Lin CF, Wang JD, Chen PH, Chang SJ, Yang YH, Ko YC: Predictors of betel quid chewing behavior and cessation patterns in Taiwan aborigines. BMC Public Health 2006, 6:27I.

21. Nelson BS, Heischober B: Betel nut: a common drug used by naturalized citizens from India, Far East Asia, and the South Pacific Islands. Ann Emerg Med 1999, 34(2):238-243.

22. Chu NS: Neurological aspects of areca and betel chewing. Addict Biol 2002, 7(I): I I I-I I4.

23. Pindborg J], Barmes D, Roed-Petersen B: Epidemiology and histology of oral leukoplakia and leukoedema among Papuans and New Guineans. Cancer 1968, 22(2):379-384.

24. Mannan N, Boucher BJ, Evans S): Increased waist size and weight in relation to consumption of Areca catechu (betel-nut); a risk factor for increased glycaemia in Asians in east London. Br J Nutr 2000, 83(3):267-275.

25. Tobacco habits other than smoking; betel-quid and arecanut chewing; and some related nitrosamines. IARC Working Group. Lyon, 23-30 October 1984. IARC Monogr Eval Carcinog Risk Chem Hum 1985, 37: I-268.

26. Mehta FS, Gupta PC, Pindborg J]: Chewing and smoking habits in relation to precancer and oral cancer. J Cancer Res Clin Oncol I 98I, 99(I-2):35-39.

27. Yen LL, Pan LY, Chen HH: Factors related to adult betel-quid chewing and cessation (in Chinese). J Med Education 200I, 5:312-323.

\section{Pre-publication history}

The pre-publication history for this paper can be accessed here:

http://www.biomedcentral.com/1471-2458/8/199/pre

pub

Publish with Bio Med Central and every scientist can read your work free of charge

"BioMed Central will be the most significant development for disseminating the results of biomedical research in our lifetime. "

Sir Paul Nurse, Cancer Research UK

Your research papers will be:

- available free of charge to the entire biomedical community

- peer reviewed and published immediately upon acceptance

- cited in PubMed and archived on PubMed Central

- yours - you keep the copyright
BioMedcentral 